\title{
Academic freedom and tenure: introduction
}

\author{
Konstantinos I. Stergiou ${ }^{1,2, *}$, Stylianos Somarakis ${ }^{1}$ \\ ${ }^{1}$ Institute of Marine Biological Resources and Inland Waters, Hellenic Centre for Marine Research, Aghios Kosmas, \\ 16777 Athens, Greece \\ ${ }^{2}$ Laboratory of Ichthyology, Department of Zoology, School of Biology, Aristotle University of Thessaloniki, \\ UP Box 134, 54124 Thessaloniki, Greece
}

\begin{abstract}
This Theme Section consists of 11 essays aiming to explore diverse issues related to academic freedom and tenure, presenting the views and thoughts of 15 scholars from different disciplines. Historical, legal, theoretical, philosophical, political and educational aspects of academic freedom and tenure are addressed; the decline in productivity of tenured faculty is questioned; and the effect of marketization of education on tenure policies and their implications are discussed. Overall, the essays recognize that academic freedom has been increasingly challenged in recent years and affected by factors such as increased commercialization, the constraints imposed by the 'western way of thinking' and neo-liberal ways of valuing, changes from a collegial to a managerial mode of organization in universities, political pressures to suppress inconvenient scientific findings, the economic crisis itself, even the current metrics of valuating research and the recent changes set by new media in disseminating ideas. We argue that today, academics can defend and promote academic freedom themselves, as has been done using various means with other aspects of academic life.
\end{abstract}

KEY WORDS: Academic freedom - Tenure $\cdot$ Education · Commercialization · Political pressure · Inconvenient scientific findings $\cdot$ Economic crisis

\section{INTRODUCTION}

\section{Academic freedom and tenure}

Professors and researchers are not ordinary workers but scholars, being subject to the judgment and criticisms of their peers through the peer-review process. They must be free to both pursue research for its own sake, even on unfashionable issues, and disseminate (including via teaching) the knowledge produced by their research. They must also be free to speak, inside and outside their working environment, against orthodoxies of thinking as well as to openly disagree with governments, political parties, the business community, administrative bodies and religious and other authorities. The above aspects constitute, in fact, the basis of academic freedom which, according to Polanyi (1958), is the backbone

*Corresponding author: kstergio@hcmr.gr,

kstergio@bio.auth.gr supporting the production and advancement of knowledge for society's benefit. Academic freedom also includes the obligation of the public authorities to respect, protect and promote it (Vrielink et al. 2011). Although academic institutions also must do so, they frequently do not (Gottfredson 2010). Academic tenure provides economic security (Horn 2015, this Theme Section) and guarantees the right to academic freedom because it provides an umbrella, protecting all those involved in producing and teaching knowledge (i.e. researchers and professors). Yet, these concepts are not static but evolve with time (Wilson 2014, Teichgraeber 2014).

The concept of academic freedom originated in Germany, with Wilhelm von Humboldt and the foundation of the University of Berlin in 1818, when the principles of 'freedom to teach' and 'freedom to learn' were established, and spread to other Euro-

() The authors 2016. Open Access under Creative Commons by Attribution Licence. Use, distribution and reproduction are unrestricted. Authors and original publication must be credited. 
pean and American universities (Karran 2009, Altbach 2009). Indeed, the phrase 'academic freedom' appears in digitized English books published as early as 1815 , and since 1895 its frequency has increased exponentially to a peak between 1950 and 1970; this coincides with the period of its legal establishment in the USA (Liszka 2011). Similarly, the phrase 'academic tenure' appears in English books as early as $1861^{1}$ and has increased exponentially since the mid-1910s, displaying a trend similar to that of academic freedom, with a maximum frequency in the mid-1970s and declining since then (Fig. 1). It is interesting to note that the number of tenured positions compared to the total number of pro-

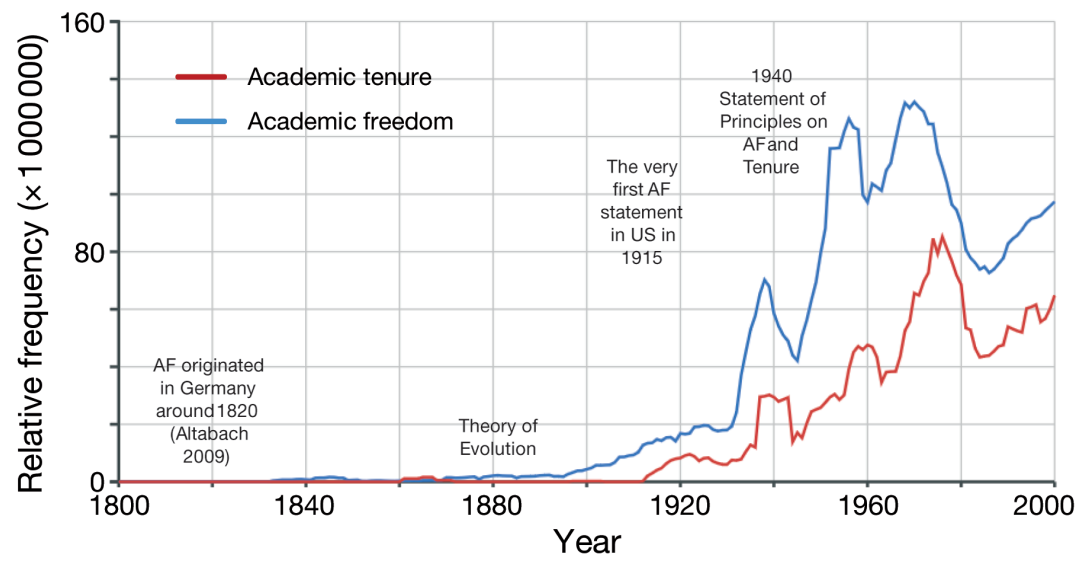

Fig. 1. Usage frequencies (relative) of all forms of the phrases 'academic freedom' (AF) and 'academic tenure' in the corpus of English books between 1800 and 2000, extracted using the Ngram Google tool (http://books.google.com/ ngrams). A detailed account of the Ngram technique is provided by Michel et al. (2011) and Lin et al. (2012); a step-by-step guide for its application is available at http://books.google.com/ngrams/info\#advanced fessors in the USA has sharply decreased during the last 40 yr from $57 \%$ in 1975 to $30 \%$ in 2009 , and is expected to reach a low threshold of 15 to $20 \%$ (Figlio et al. 2013).

Academic freedom and tenure are highly complex, interactive concepts (Horn 2015, Teichgraeber 2014), which attract the attention of academics from all disciplines. A bibliometric search in the Scopus database (www.scopus.com) showed that between 1970 and 2014 a total of 49 articles having 'academic freedom' and 171 having 'academic tenure' in their title were published (Fig. 2). The number of articles increased from an average of 3.82 and 0.73 articles $\mathrm{yr}^{-1}$ between 1970 and 1980, for 'academic freedom' and 'academic tenure', respectively, to an average of 31.7 and 7.8 articles $\mathrm{yr}^{-1}$ between 2010 and 2014. These essays were published in journals belonging to almost all subject areas of the Scopus database, with the majority appearing in social sciences, multidisciplinary, arts, humanities and medical journals.

This Theme Section on academic freedom and tenure was triggered by that of K.I. Stergiou and A.C. Tsikliras (eds) on global university rankings, published in 2014, in which (among other things) it was recognized that the commercialization of higher education in recent decades parallels the polemics against tenure and the decrease in tenured faculty positions in various countries in favor of non-tenured faculty (positions that are not covered by academic

${ }^{1}$ For instance, struggles for tenure in the USA paralleled those of other labors (e.g. steel workers) in the late 19th century (Stephey 2008) freedom; Altbach 2009, Horn 2015). The present Theme Section is topical, given that both academic freedom and tenure are currently under stress (Altbach 2009).

\section{Issues uncovered in this Theme Section}

This Theme Section consists of 11 essays aiming to explore diverse issues related to academic freedom and tenure through the views and thoughts of 15 scholars from 8 countries (Belgium, Canada, Greece, Ireland, Italy, Spain, UK and the USA) and different disciplines, from biology, ecology and fisheries to business, education and philosophy. These essays discuss historical, legal, theoretical, philosophical, political and educational aspects, the alleged loss of

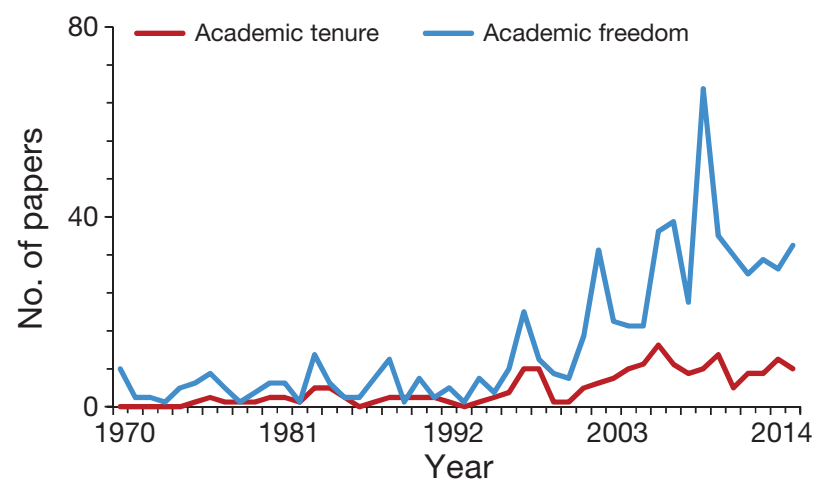

Fig. 2. Number of essays published between 1970 and 2014 having 'academic freedom' and 'academic tenure' in their title, based on the Scopus bibliometric database (www. scopus.com) 
productivity of tenured faculty, and the effect of marketization of education on tenure policies.

Donoghue (2015a) reviews the legal history of academic freedom and subsequently explores how university administrators can now take ownership of teaching materials. He concludes that the legal redefinition of academic freedom and the erosion, over the course of the 20th and early 21st centuries, of what was known as the 'teacher exception' with replacement by the work-for-hire rule have rendered universities more workplaces under management, and university professors conventional workers.

Nelson (2015) deals with current fundamental changes in the character of higher education, such as the gradual replacement of tenured faculty with parttime teachers. He argues that such changes serve the political goal to de-fund higher education, thus making it easier to impose the corporate model of instrumental education, which is merely devoted to skills acquisition and job training. He concludes that an alternative educational model is required.

Horn (2015) describes the history of academic tenure and the concepts of academic freedom in Canadian universities since the mid-19th century. He concludes that 'tenure during good behavior' (i.e. professors are secure except in cases of proven gross incompetence, duty neglect or moral turpitude) has supported the academic freedom of faculty despite the new challenges that academic freedom faces.

Traianou (2015) explores how, since the 1980s, UK governments have increasingly intervened in higher education, based on the assumption that the role of universities is to serve the economy by maximizing and measuring the 'returns' on public investment. She argues that this attitude brought about a change within universities from a collegial organization mode towards a managerial one; a change that considerably reduced academic freedom.

Akrivou (2015) identifies threats relevant to the creation of new knowledge. These threats, which are recognized by researchers across heterogeneous disciplines, remain largely unaddressed from institutional and political decision makers in higher education. As a result, Europe is lacking a good new knowledge basis to sustainably deal with an emerging variety of problems (e.g. socio-behavioral, environmental, health). The causes are linked to neo-liberal ways of understanding and the valuing of researchers and their work. However, embracing an Aristotelian way of understanding habits and habitus and personal and collective responsibility beyond Bourdieu's determinism allows hope for change.
Pauly (2015) maintains that academic tenure is one of the few obstacles to the strategy of the Canadian government, which has intensified since 2006, to silence environmental researchers in federal governmental laboratories in the case of 'inconvenient' findings (e.g. overfishing of northern cod, virus in farmed salmon, environmental and health effects of exploiting tar sands and Arctic offshore oil) ${ }^{2}$.

Stergiou \& Machias (2015) discuss the abolishment of tenure and the change in the status of Greek researchers through a new law for research that was passed in December 2014. This constitutes the last nail in the coffin for Greek research, which has suffered several blows (i.e. drastic budgetary cuts, no opening of positions, severe salary cuts, and austerity-driven brain-drain) because of the recent economic crisis.

Boero (2015) attests that the current system of 'metrics' for evaluating research quality, which is based on impact factors and citations, actually allows little room for scientists to develop ideas that go against the mainstream before they get tenure. He argues that scientists can pursue and publish their new ideas after they receive tenure, but by then it might be 'too late'.

Lynch \& Ivancheva (2015) discuss the relationships between university autonomy, ethics and academic freedom, the limitations imposed by the increasing casualization of employment on the freedom to teach and publish, and the constraints imposed by western thinking on academic freedom. In addition, the authors point out how important is to distinguish between institutional autonomy and individual academic freedom, and to separate these 2 concepts from the freedom of academics to create and maintain new scholarship fields.

Nikolioudakis et al. (2015) tested the hypothesis that tenure reduces the productivity of senior faculty, which is the main argument fueling the polemics against tenure. They collected and analyzed the number of publications of 2136 current full professors of natural sciences, from 123 universities distributed across 15 countries, for the period spanning 1996 to 2014. Their results showed that the long-term productivity of full professors increased, irrespective of subject field and geographic area. This suggests that tenure does not lead to motivation loss and academic 'deadwood'.

\footnotetext{
2The Canadian federal election of 19 October 2015 led to a replacement of the Conservative Government by the Liberal Government, which has since reversed many of these policies
} 
Minerva (2015) discusses the usefulness and the potential threats to academic freedom of the media for the dissemination of research results outside academia. She concludes that the concept of academic freedom should be reconsidered in the light of the changing landscape in the dissemination of ideas set by social media, and that new strategies must be developed for minimizing the potential threats to academic freedom.

\section{EPILOGUE}

Academic freedom has been challenged in recent years. The essays presented in this Theme Section recognize that it has been increasingly affected by factors such as increased commercialization, constraints imposed by the western way of thinking and neo-liberal ways of valuing, changes from collegial to managerial modes of organization within universities, political pressures to suppress inconvenient research findings, the economic crisis itself, even the current system of metrics for evaluating research and the recent changes set by new media in disseminating ideas. The role of social media in particular requires further thorough assessment given that they can be used as a vehicle by which administrators can keep professors under a tighter watch (Donoghue 2015b; Minerva 2015, this Theme Section). There are also other aspects that were not addressed in this Theme Section. For instance, it has been asserted that the commercialization of education amplifies bureaucracy by increasing the number of well-paid managers, who in turn create more manager positions, thus generating hyperbureaucracy (Tahir 2010). One might hypothesize that bureaucrats have limited (if any) perception and sensitivity to academic freedom (Tahir 2010) (as well as to other academic matters); an open question for future studies.

As Gottfredson (2010) puts it: 'academic freedom .... is not often defended by academics themselves, and ... yet, requires no heroic efforts for collective enjoyment if scholars consistently contribute small acts of support to prevent incursions.' . Nowadays, the internet provides an opportunity for academics to defend and promote academic freedom, as is done

\footnotetext{
${ }^{3} \mathrm{AFAF}$ was founded in 2006 'as a campaigning group for all lecturers, academic-related staff, students and researchers who wanted to defend unimpeded enquiry and expression..., and has taken up the case for free speech and academic freedom around the world' (AFAF, www.afaf.org.uk )
}

with other aspects of academic life (e.g. the San Francisco Declaration on Research Assessment [DORA], http://am.ascb.org/dora/, for not using impact factors as a surrogate measure of quality at any assessment; Scholarly Open Access, http://scholarlyoa.com/publishers/, for monitoring of predatory journals). To that end, Academics For Academic Freedom (AFAF, www.afaf.org.uk) ${ }^{3}$ can be one potential vehicle for this. At the same time, given that academic freedom has to have a legal status (i.e. a privileged version of freedom of speech in individual countries' constitutions and traditions of legal decisions), academics should also litigate the status of academic freedom. In fact, academics taking full control of academic matters in their hands will be the full manifestation of academic autonomy, providing the best service to society with the university being 'a place from where to speak' (Badley 2009, p. 146).

Acknowledgements. The authors thank Drs. Akrivou, Boero, Donoghue, Horn, Lynch, Minerva, Nikolioudakis, Pauly, Traianou, for useful comments and suggestions.

\section{LITERATURE CITED}

Akrivou K (2015) Towards (more) integrity in academia, encouraging long-term knowledge creation and academic freedom. Ethics Sci Environ Polit 15:49-54

Altbach PG (2009) Academic freedom: a realistic appraisal. Int Higher Educ 57:2-3. http://ejournals.bc.edu/ojs/ index.php/ihe/article/view/8450 (accessed 20 Dec 2015)

Badley G (2009) A place from where to speak: the university and academic freedom. Br J Educ Stud 57:146-163

Boero F (2015) Scientists can be free, but only once they are tenured. Ethics Sci Environ Polit 15:63-69

Donoghue F (2015a) Academic freedom, the 'teacher exception', and the diminished professor. Ethics Sci Environ Polit 15:7-15

Donoghue F (2015b) Watch what you say. The Chronicles of Higher Education, 28 Sep 2015. http://chronicle.com/ article/WatchWhatYouSay/233405 (accessed 10 Jan 2016)

Figlio DN, Schapiro MO, Soter KB (2013) Are tenure track professors better teachers? NBER working paper no. 19406, The National Bureau of Economic Research. www.nber.org/papers/w19406 (accessed 20 Nov 2015)

Gottfredson LS (2010) Lessons in academic freedom as lived experience. Pers Individ Dif 49:272-280

Horn M (2015) Tenure and academic freedom in Canada. Ethics Sci Environ Polit 15:23-37

Karran T (2009) Academic freedom: in justification of a universal ideal. Stud High Educ 34:263-283

Lin Y, Michel JB, Aiden EL, Orwant J, Brockman W, Petrov S (2012) Syntactic annotations for the Google Books Ngram Corpus. Proc 50th annu meet assoc computational linguistics, Vol 2: demo papers, ACL, Jeju, 8-14 July 2012

Liszka J (2011) Academic freedom: a basic guide. University of Alaska, Anchorage, AK. www.uwosh.edu/chancellor/ 
communications/campus-civility/Start $\% 20$ Talking- $\% 20$ Academic\%20Freedom.pdf (accessed 10 Jan 2016)

Lynch K, Ivancheva M (2015) Academic freedom and the commercialisation of universities: a critical ethical analysis. Ethics Sci Environ Polit 15:71-85

Michel JB, Shen YK, Aiden AP, Veres A and others (2011) Quantitative analysis of culture using millions of digitized books. Science 331:176-182

Minerva F (2015) Rethinking academic freedom. Ethics Sci Environ Polit 15:95-104

Nelson C (2015) Dystopia is now: the threats to academic freedom. Ethics Sci Environ Polit 15:17-22

Nikolioudakis N, Tsikliras AC, Somarakis S, Stergiou KI (2015) Tenure and academic deadwood. Ethics Sci Environ Polit 15:87-93

Pauly D (2015) Tenure, the Canadian tar sands and 'Ethical Oil'. Ethics Sci Environ Polit 15:55-57

Polanyi M (1958) Personal knowledge: towards a postcritical philosophy, 1st edn. Routledge \& Kegan Paul, London

Stephey MJ (2008) A brief history of tenure. Time. 17 Nov 2008. http://content.time.com/time/nation/article/0,8599,

Editorial responsibility: Darryl Macer,

Bangkok, Thailand
1859505, 00.html (accessed 20 Dec 2015)

Stergiou KI, Machias A (2015) Nailing down 'academic' freedom and tenure in Greek research institutions. Ethics Sci Environ Polit 15:59-62

Tahir T (2010) The irresistible rise of academic bureaucracy. The Guardian. 30 March 2010. www.theguardian. com/education/2010/mar/30/academic-bureaucracy-risemanagers-higher-education (accessed 28 Nov 2015)

Teichgraeber RF III (2014) Tenure matters: an historian's perspective. American Association of University Professors, Journal for Academic Freedom, Vol 5 (2014). www. aaup.org/reports-publications/journal-academic-freedom/ volume-5-2014/tenure-matters-historian \%E2 \%80\%99sperspective (accessed 20 Dec 2015)

Traianou A (2015) The erosion of academic freedom in UK higher education. Ethics Sci Environ Polit 15:39-47

Vrielink J, Lemmens P, Parmentier S, the LERU Working Group on Human Rights (2011) Academic freedom as a fundamental right. Procedia Social and Behavioral Sciences 13:117-141

Wilson JK (2014) A history of academic freedom in America. $\mathrm{PhD}$ thesis, Illinois State University, Normal, IL

Submitted: January 25, 2016; Accepted: January 25, 2016 Proofs received from author(s): March 1, 2016 